\title{
Aspects of oophagyin Alopias vulpinus (Elasmobranchii,Alopiidae) in the southern Brazil
}

\begin{abstract}
Oophagy of the genus Alopias was described by several authors, nevertheless, this paper presents some new aspects of the oophagy of $A$. vulpinus. ${ }^{1}$ Four embryos of $A$. vulpinus, being three males with total lengths of $115.5 \mathrm{~cm}(3.2 \mathrm{~kg}), 116.5 \mathrm{~cm}(3.6 \mathrm{~kg})$, and $118.8 \mathrm{~cm}$ $(3.3 \mathrm{~kg})$, and a female with $118.6 \mathrm{~cm}(3.0 \mathrm{~kg})$, were obtained from a female caught by Brazilian artisanal fishing using in shore gillnet at a depth of $4.5 \mathrm{~m}$ off Peruibe City, Sao Paulo State, Brazil in November, 2007. Five oocytes were integer, and the size ranged from 67 to $71 \mathrm{~mm}$. This study found clear evidence that embryos of $A$. vulpinus ingest the whole oocyte. No traces of smaller siblings were found in the four embryos stomachs, so the species probably do not perform adelphophagy.
\end{abstract}

Keywords: common thresher shark, food of embryos, oocytes, matrotrophic viviparity

\author{
Volume 2 Issue 2 - 2018
}

\author{
Malavasi-Bruno CE,' Alberto Ferreira de \\ Amorim $^{2}$ \\ 'Department of Surgery, Faculty of Veterinary Medicine and \\ Animal Science, University of São Paulo, Brazil \\ ${ }^{2}$ Instituto de Pesca, Agência Paulista de Tecnologia dos \\ Agronegócios, Brazil
}

Correspondence: Alberto Ferreira de Amorim, Instituto de Pesca, Agência Paulista de Tecnologia dos Agronegócios, Brazil, Email prof.albertoamorim@gmail.com

Received: February 21, 2018| Published: April 25, 2018

\section{Introduction}

Oophagy is a form of matrotrophic viviparity where, after initial yolk-sac nutrition, developing embryos ingest unfertilized eggs to support further development. The Lamniformes sharks are oophageal..$^{2-7}$ The oophagy in the Lamniforms, throughout most of their pregnancy, mothers continuously produce unfertilized eggs which the developing embryos ingest and store in a large bulging yolk stomach ${ }^{7}$ According to Cadenat ${ }^{4}$ oocytes are consumed by the developing embryos. This has been confirmed by Okate \& Mizue ${ }^{8}$ for A. pelagicus, by Gilmore ${ }^{9} \&$ Moreno, Moron ${ }^{10}$ for $A$. superciliosus, and Gubanov ${ }^{11,12}$ for Alopias vulpinus. This brief communication records the occurrence of integer oocytes in stomachs of Alopias vulpinus embryos.

\section{Material and methods}

Four embryos of Alopias vulpinus obtained from a pregnant female caught in November 2007 by Brazilian artisanal fishermen using gillnet at $4.5 \mathrm{~m}$ depth off Peruibe City, Sao Paulo State, Brazil were donated to Fishery Research State Instituto "Instituto de Pesca" (Figure 1). The embryos were identified and measured according to Compagno $^{13}$ and weighed with digital scale, in grams. The embryos had integer oocytes in their oral cavity were placed upside down to remove them and also had the stomachs opened

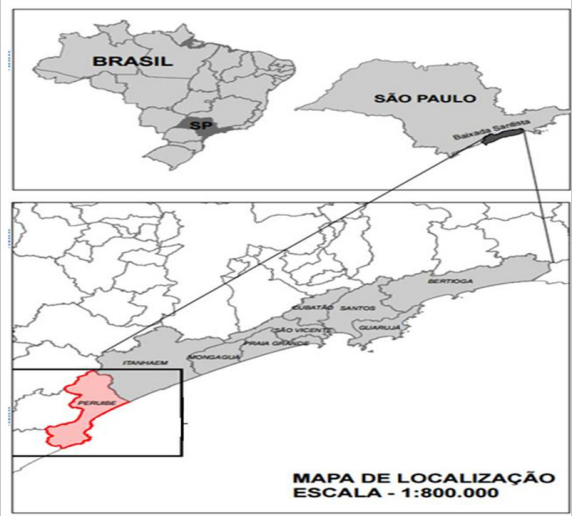

Figure I Maps of Peruibe City, Sao Paulo State, Brazil.

\section{Results and discussion}

Four embryos of $A$. vulpinus were obtained from a female caught being three males with total lengths of $115.5 \mathrm{~cm}(3.2 \mathrm{~kg}), 116.5 \mathrm{~cm}$ $(3.6 \mathrm{~kg})$, and $118.8 \mathrm{~cm}(3.3 \mathrm{~kg})$, and one female with $118.6 \mathrm{~cm}(3.0 \mathrm{~kg})$. According to the characteristics of pigmentation, aspects identical to adult and embryo size were in the athermal stage, based on Bigelow \& Schroeder ${ }^{13}$ ranging from 114 to $159 \mathrm{~cm}$. The embryos were probably performing oophagy and close to birth. Some embryos from 116.5 to $124 \mathrm{~cm}$ were observed in November 2004 and newborn and juveniles are reported in shore waters from April to July. ${ }^{14}$ In Southern Brazil it was observed the presence of pregnant female, neonate and juvenile of Alopias vulpinus, from December to March. ${ }^{14,15}$ One male embryo had an integer oocyte in the oral cavity and in order to extract it the embryo was placed upside down. In addition to this oocyte, three others dropped from his stomach. The same procedure was done for the others and one more oocyte fell from the female (Figure 2). Five oocytes were integer, and the size ranged from 67 to $71 \mathrm{~mm}$. In addition, all the embryos'stomachs were opened observing a net mass of oocyte. This fact suggests that the embryos swallowed integer oocytes as a food source. According to Moreno et al. ${ }^{1}$ The teeth can remain embedded or hidden until shortly before birth. Therefore, the oocyte capsule even being eaten did not break. Some authors as Shann, ${ }^{2}$ Springer, ${ }^{3}$ Cadenat, ${ }^{4}$ Gilmore $^{5}$ and Hamlett ${ }^{7}$ mentioned the oophagy in Lamniformes. According to Gubanov ${ }^{11} A$. vulpinus young fetus after resorption of their primitive yolk reserves absorbed eggs at the time of their descent into the oviduct, so the stocks of nutrients enable them to continue their development in the mother uterus without any connection with uterine walls and without specialized system enabling the absorption of nutritive juices thereof. Nevertheless this author did not mention anything about how embryo can ingest the oocyte. Moreno et al. ${ }^{1}$ studied the reproductive biology and phenology of A. Vulpinus caught at some areas of Mediterranean and Atlantic oceans, giving, among others, information about size and morphology of embryos. Nevertheless, it has not been demonstrated as the ingestion of egg capsule occurs. This study found clear evidence that embryos of A. vulpinus of $115.5 \mathrm{~cm}$ or larger ingest the whole oocyte. Capsule was whole in the stomach of the fish with out chewing, demonstrating that the rupture occurs in the stomach, characterizing the mode of ingestion. The absence of smaller siblings 
or parts of it in the stomach of the embryos suggests that the species does not perform adelphophagy.

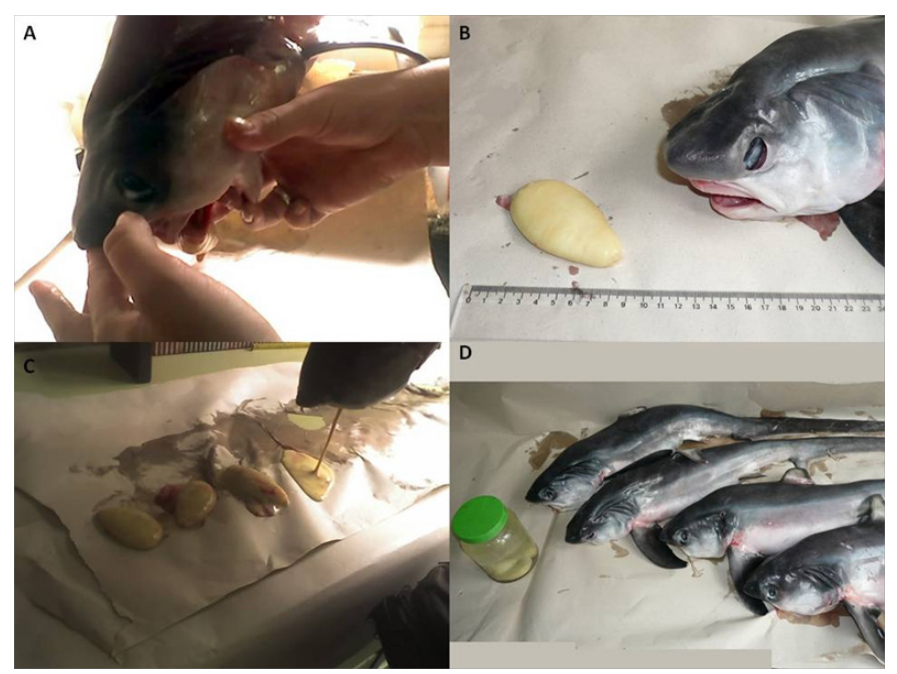

Figure 2 Alopias vulpinus: (A) Exemplar upside down for expulsion of the oocytes from the mouth; (B) Oocyte and embryo; (C) Integer oocyte and broken capsule; and (D) Four embryos of A. vulpinnus.

\section{Conclusion}

This study found clear evidence that embryos of $A$. vulpinus of $115.5 \mathrm{~cm}$ or larger ingest the whole oocyte. The absence of smaller siblings or parts of it in the stomach of the embryos suggests that the species does not perform adelphophagy.

\section{Acknowledgements}

None.

\section{Conflict of interest}

The authors declare that there is no conflict of interest in this manuscript.

\section{References}

1. Moreno JA, Moron J, Parajúa JI. Biología reproductiva y fenologia de Alopias vulpinus (Bonnaterre 1788) (Squaliformes: Alopiidae) en el Atlántico nor-oriental y Mediterráneo occidental. [Reproductive biology and phenology of Alopias vulpinus (Bonnaterre, 1788) (Squaliformes: Alopiidae) in the northeastern Atlantic and western Mediterranean]. Scientia Marina. 1989;53:37-46.

2. Shann EW. The embryonic development of the porbeagle shark, Lamnacornubica. Proc Zool Soc. 1923;11:161-171.

3. Springer S. Oviphagous embryos of the sand shark, Odontaspistaurus. Copeia. 1948;3:153-157.

4. Cadenat J. Note d'Ichtyologieouest-africaine XV-Sur un Requin-Renard nouveaupour la fauned'Afrique Occidentalefrançaise Alopiassuperciliosus (LOWE,1840). Bulletin de I' IFAN. 1956;4:1257-1266.

5. Gilmore RG. Reproductive biology of lamnoid sharks. Environemental biology of fishes. 1993;38(1-3):95-114.

6. Hamlett WC, Koob TJ. Sharks, Skates and Rays: The biology of elasmobranch fishes. Johns Hopkins University Press. 1999. p. 515.

7. Hamlett WC. Reproductive biology and phylogeny of Chondricthyes: sharks, batoids, and chimaeras. Science Publishers. 2005. 575 p.

8. Okate T, Mizue K. Direct evidence for oophagy in thresher shark, Alopiaspelagicus. Japanese journal of Ichthyology. 1981;28:171-172.

9. Gilmore RG. Observations on the Embryos of the Longfin Mako, Isuruspaucus, and the Bigeye Thresher, Alopiassuperciliosus. Copeia. 1983;2:375-382.

10. Moreno JA, Moron J. Reproductive biology of the bigeye thresher shark Alopiassuperciliosus (Lowe, 1839). Aust J Mar Freshwater Res. 1992;43(1):77-86.

11. Gubanov WL. On the biology of the thresher shark, Alopias vulpinus (Bonnaterre) in the northwest Indian Ocean. Journal of Ictiology. 1972;12:591-600.

12. Gubanov YP. The reproduction of some species of pelagic sharks from the equatorial zone of the Indian Ocean. Journal of Ictiology. 1978;18:781792.

13. Bigelow HB, Schroeder WC. Sharks: Fishes of the Western North Atlantic. Sears Foundation for Marine Research. 1984;559-576.

14. Mancini PL, Amorim AF. Embryos of common thresher shark, Alopias vulpinus in southern Brazil, South Atlantic Ocean. Journal of fish biology. 2006;9:318-321.

15. Gadig OBF, Namora RC, Motta FS. Dados sobre jovens do tubarão raposa, Alopias vulpinus (Bonnaterre, 1788) (Chondrichthyes: Alopiidae), comcomentários sobre a distribuição da familiaAlopidae no Brasil. Arquivos de Ciencias do Mar. 2001;34:77-82. 